\title{
Reviews
}

-

Tom Stevenson, Julius Caesar and the Transformation of the Roman Republic. Routledge, 2015, pp.212, ISBN: 978-1-13880822-5

$\mathbf{J}$ ulius Caesar, one of the most interesting and fascinating characters of the Roman Republic, never stops to amaze and to cause new questions and new interpretations about his actions about his ideas and about the history of his time, the twilight of the Republic.

Even if the subject "Julius Caesar" is well known and well-trodden, yet there are new manners to tell his story, new manners to illustrate the events and the aspects (politically, economically, socially and military) in order to create different views about various historical sequences.

The brand new book of Tom Stevenson, Julius Caesar and the Transformation of the Roman Republic, represents an excellent biography mainly for the beginners. In addition to the main biographical sequences of Caesar's life, a clear and concise presentment of the main socio-political events of the $1^{\text {st }}$ century B.C., in the future heart of the Roman Empire is more than welcome. Easy to read and understand, the book represents a perfect start for study the end of the Roman Republic and the changes that occurs in this twisted century.

The book is divided in 12 parts, the last pages containing a table of events (100-44 B.C.) and some useful biography.

The first chapter (pp.1-15) presents Julius Caesar's influence in the Western European Culture, by analysing the "idea" of Caesar, his actions and ideas and their recoil through history. More than that, the author presents some attitudes of ancient and modern writers (positive and negative) about Caesar: the man who eliminated the corrupt senators and their factions or an extremely selfish man in search for supreme political power.

In the second chapter, Imperium (pp.15-35), the author illustrates the geography of power in the landscape of year 100 B.C., presenting the main events that occurs in the time of Caesar's birth on 12 July 100 B.C. when the Romans, as the author wrote, were already an imperial people. The author analyse here the history of the Roman Republic from the $2^{\text {nd }}$ century B.C. during Rome's expansions wars to the episodes of Tiberius and Caius Gracchus following the main political struggles and socio-economic changes of the century.

In the third chapter, Nobilis (pp. 35-51) Stevenson follows Caesar's historical evolution as a young Roman noble, during 100-70 B.C. Caesar is figured here in close connection with his family and birth imperatives that governed his later career. The author describes further the childhood of Caesar during the civil wars between Marius and Sulla , the later political connexions of Caesar with Sulla and continues with the election of Caesar as tribunus militum and the first consulship of Crassus and Pompey in 70 B.C.

In the next two chapters, Ambitio (pp. 51-63) and Pietas (pp. 63-79), the author includes the events of Caesar's life from the 70 B.C. to the first consulship of Caesar in 59 B.C. Stevenson compares and illustrates a typically cursus honorum of a randomly young patrician with the one of Caesar altogether with a parallel description of the historical background dominated by Pompey, Crassus and their political factions.

\section{Horațiu Cociș}

University 'Babes-Bolyai' of Cluj-Napoca hcocis@yahoo.com

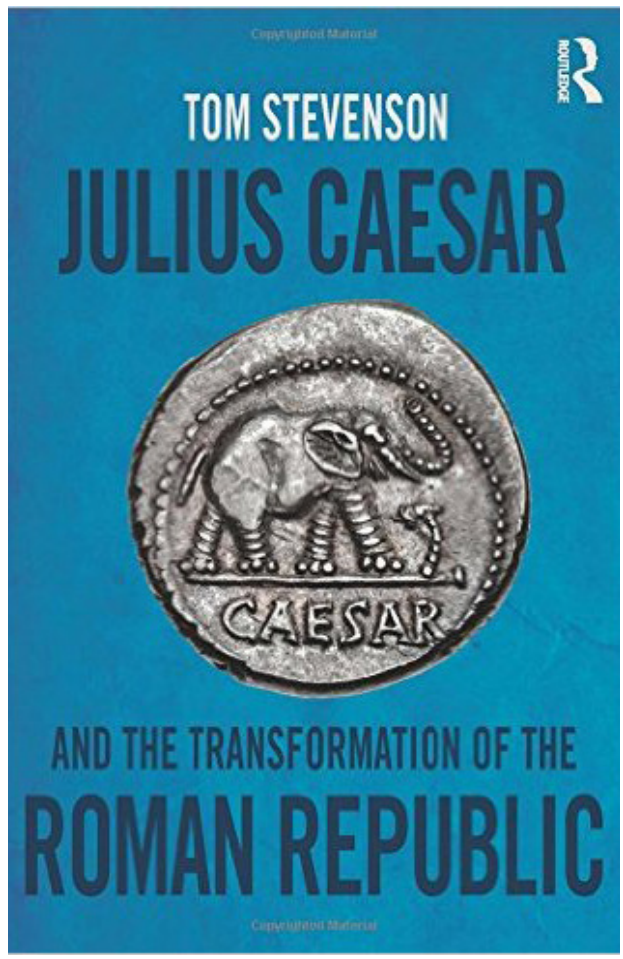

DOI: $10.14795 /$ j.v2i3.128

ISSN $2360-266 \mathrm{X}$

ISSN-L 2360 - 266X 
Gloria (pp. 79-95) and Victoria (pp. 95-109) are the next two chapters in which Stevenson follows Caesar in the war with the Gauls but also compares the evolution of the war, having Caesar as the main character with the political situation from Rome. He describes very clear antonymic actions and interest of Pompey and Caesar and the later events that prepared the civil war. The red thread is followed back by the author to 53 B.C. the Crassus' death and the remaining of the above-mentioned characters as leading men in Rome. The next chapter, Dignitas (pp. 109-123) presents the evolution of the political relations between Caesar and Pompey that led to the civil war.

Fortuna (pp. 123-139) is a very clear analyse of Caesar's civil war. Following him through all the major conflicts of the war as Ilerda, Dyrrachium, Alexandria or Pharsalus, Stevenson outlines the military tactics used by both of the combatants, he describes and explains in detail every battle and episode of the war, creating a much more colourful image than in the case of Gallic wars.

In the next two chapters, Clementia (pp. 139-153) and Libertas (pp. 153-167) the author introduces the reader in the long debate about the years when Caesar was dictator and dictator perpetuo. The chapters turns out to be a useful comparative introduction in the years of the dictatorship (49-44 B.C.). Caesar's dictatorship is dissected by the author in two parts: one part analyses the positive elements of the dictatorship regime, as reforms and honours integrated in a discussion about the concepts of monarchy at Rome. The second part, the next chapter, describes how the dictator perpetuo supressed the nobility and the popular actions using his perpetual power, this fact leading to the death of libertas, probably the main reason for creating the conspiracy which assassinate him in the end.

The last chapter, Res Publica (pp. 167-181) concludes about the main topic of the book, namely how Caesar and the events that occurred in those decades could transform the republic. There are also presented here some opinions, ancient and modern ones, about the fall of the Republic and the transformation of this complicated mechanism that was the Republican Rome. 